\title{
Volatile Organic Compounds Emitted by Fungal Associates of Conifer Bark Beetles and their Potential in Bark Beetle Control
}

\author{
Dineshkumar Kandasamy $^{1}$ • Jonathan Gershenzon ${ }^{1}$ (D) $\cdot$ Almuth Hammerbacher ${ }^{2}$
}

Received: 7 June 2016 / Revised: 14 August 2016 / Accepted: 7 September 2016 / Published online: 29 September 2016

(C) The Author(s) 2016. This article is published with open access at Springerlink.com

\begin{abstract}
Conifer bark beetles attack and kill mature spruce and pine trees, especially during hot and dry conditions. These beetles are closely associated with ophiostomatoid fungi of the Ascomycetes, including the genera Ophiostoma, Grosmannia, and Endoconidiophora, which enhance beetle success by improving nutrition and modifying their substrate, but also have negative impacts on beetles by attracting predators and parasites. A survey of the literature and our own data revealed that ophiostomatoid fungi emit a variety of volatile organic compounds under laboratory conditions including fusel alcohols, terpenoids, aromatic compounds, and aliphatic alcohols. Many of these compounds already have been shown to elicit behavioral responses from bark beetles, functioning as attractants or repellents, often as synergists to compounds currently used in bark beetle control. Thus, these compounds could serve as valuable new agents for bark beetle management. However, bark beetle associations with fungi are very complex. Beetle behavior varies with the species of fungus, the stage of the beetle life cycle, the host tree quality, and probably with changes in the emission rate of fungal volatiles. Additional research on bark beetles and their symbiotic associates is necessary before the basic significance of
\end{abstract}

Electronic supplementary material The online version of this article (doi:10.1007/s10886-016-0768-x) contains supplementary material, which is available to authorized users.

Jonathan Gershenzon

gershenzon@ice.mpg.de

1 Department of Biochemistry, Max Planck Institute for Chemical Ecology, Hans-Knöll Str. 8, 07745 Jena, Germany

2 Department of Microbiology, Forestry and Agricultural Biotechnology Institute, University of Pretoria, Private Bag X20, Hatfield, Pretoria 0028, South Africa ophiostomatoid fungal volatiles can be understood and their applied potential realized.

Keywords Symbiosis · Pest management · Fusel alcohol · Aliphatic alcohol · Aromatic compound · Terpenoid · Ophiostoma · Grosmannia, Endoconidiophora · Ips · Dendroctonus

\section{Introduction}

Conifer bark beetles are phloem-feeding insects with immense ecological importance in coniferous forest ecosystems throughout the world. By attacking old and wind-thrown trees, these insects serve to rejuvenate forests by recycling nutrients. However, once beetle populations reach a threshold density a number of the more aggressive species attack healthy trees (Bentz et al. 2010; Raffa et al. 2008; Wermelinger 2004). During such outbreaks, bark beetles can destroy millions of hectares of living forest, with great economic and ecological implications. During the last 25 years, bark beetle outbreaks have increased rapidly worldwide as a result of climate change, with the increased frequency of high temperatures, droughts, and windstorms (Kausrud et al. 2012; Kurz et al. 2008). These conditions have allowed bark beetle populations to increase, and particularly to expand their ranges into forest ecosystems containing tree species that are susceptible to attack because of their lack of any prior evolutionary experience with these insects (Bentz et al. 2010; Cudmore et al. 2010; Erbilgin et al. 2014). Hence, there is a strong need for new approaches to bark beetle control.

Aggressive bark beetle species colonize mainly pine and spruce trees via a characteristic sequence of behaviors. First, a pioneer beetle (male or female depending on the species) identifies a suitable host tree and releases aggregation pheromones 
that attract conspecifics of one or both sexes. The aggregation pheromones are produced de novo by the bark beetles, and also by utilizing some of the host compounds as precursors. Additionally, some microbes associated with bark beetles may play a role in pheromone production (Blomquist et al. 2010; Brand et al. 1976; Vite et al. 1972; Wood 1982a; Zhao et al. 2015). After mating, female beetles construct vertical galleries in the phloem tissue. Once enough beetles are recruited to the host tree, beetles produce short-range anti-aggregation pheromones that repel and divert newly arriving beetles to neighboring trees, thus avoiding intra-specific competition for resources and space. Eggs are laid on the sides of the vertical maternal galleries made by the parent beetles, and the newly hatched larvae make their own feeding tunnels at right angles. Larvae feed on both the phloem tissue and the symbiotic microbes with which they are associated (Ayres et al. 2000; Hodges et al. 1968; Six 2012, 2013). At the end of each larval tunnel, a chamber is excavated where the larva pupates. Adult beetles emerge from the gallery through exit holes and attack new trees under favorable conditions, or overwinter underneath the host tree bark or in the soil (Sauvard 2004). Volatile organic compounds (VOCs) play a role in many stages of the bark beetle life cycle including attraction to hosts, aggregation for mass attack, and repulsion of competitors. The identification of volatile chemicals that act as pheromones and related attractants were landmark achievements in the developing science of chemical ecology (e.g., Silverstein et al. 1966, 1968; Wood et al. 1967). Since then, these compounds have been employed with varying success to trap and monitor bark beetle populations (Bakke 1991), and also could play a role in new control efforts.

The interactions of bark beetles with their conifer hosts have long been known to be mediated at least in part by microbes (Adams et al. 2013; Brand et al. 1976, 1977; Six 2013; Therrien et al. 2015). This concept has expanded in recent years due to our increasing knowledge about insect-microbe symbiosis in general, and how the formation of mutualisms with microbes gives insects access to new resources, supplements their nutrition, and allows them to adapt to niches that are otherwise unfavorable (Janson et al. 2008). Bark beetles have symbiotic associations with fungi including Ascomycetes of the genera Ophiostoma, Grosmannia, Ceratocystiopsis, and Endoconidiophora, and a few species also have associations with Basidiomycetes of the genus Entomocorticium (de Beer et al. 2014; Zipfel et al. 2006). Ophiostoma, Grosmannia, and Ceratocystiopsis form a monophyletic group in the Ophiostomatales, whereas Endoconidiophora is in the order Microascales (Spatafora and Blackwell 1994). Some of these fungi grow from the beetle galleries into the phloem and sapwood (living xylem) where their dark mycelium causes extensive bluish-grey or blackish discoloration of the wood. The fungi associated with coniferfeeding beetles are saprophytic, such as Ophiostoma species, or necrotrophic, such as Grosmannia (whose asexual phase is known as Leptographium) and Endoconidiophora species (de Beer et al. 2014; Harrington 2005). Ophiostoma and Grosmannia species exhibit either no, weak, or moderate pathogenicity. Endoconidiophora species, on the other hand, are highly pathogenic and can kill healthy conifers when artificially inoculated (Krokene and Solhheim 2002). However, the role of E. polonica in killing trees is much debated and has not been demonstrated outside of artificial inoculations (Six and Wingfield 2011). The roles of these ophiostomatoid fungi vary greatly depending upon beetle life strategy and species. While the beetle serves as a fungal vector, boring the entry hole and inoculating the host tree, the fungus may supply the beetle with nutrients, degrade host defenses, and help kill the tree, which often is correlated to brood fitness (Bentz and Six 2006; Hammerbacher et al. 2013; Krokene and Solhheim 1998). The close interaction between bark beetle and fungus are likely to be mediated by VOCs emanating from the fungus that attract or repel beetles depending on the species, environmental conditions, or stage of the life cycle. Thus, it may be possible to exploit these compounds for control of bark beetles.

This review explores the possibility that fungal volatiles could be applied to the management of bark beetle outbreaks. We begin by briefly outlining our current understanding of the interactions between frequently studied conifer bark beetles and their symbiotic fungi. Next, we survey the types of chemical compounds emitted by the fungal symbionts and examine what is known about their roles in fungi-beetle relationships. Finally, we discuss the potential uses of these volatiles in controlling bark beetle attacks.

\section{Fungal Associates Play Important Roles in Bark Beetle Life History}

\section{The Eurasian Spruce Bark Beetle Forms Inconsistent Associations with Ophiostomatoid Fungi Ips typographus} L., the Eurasian bark beetle, is the most aggressive primary bark beetle that attacks Norway spruce trees (Picea abies (L.) Karst.) in Europe and northern Asia (Christiansen and Bakke 1988). Ips typographus has no specialized integumental structures to transport symbiotic microbes, such as sac-like mycangia lined with secretory glands. Instead, several microbe species are carried in non-glandular pit-like structures on the exoskeleton, on pits and punctures of the head and pronotum, on the elytra, and perhaps in the beetle's gut (Furniss et al. 1990). Pathogenic fungal associates are thought to play an important role in host colonization by I. typographus and in accelerating tree death (Krokene and Solhheim 1998). Fungi also may provide nutrients to I. typographus, metabolize host toxins, or exhaust tree defenses by over-stimulating the production of oleoresins and phenolic compounds (Hammerbacher et al. 2013; Zhao et al. 2011), but these benefits have not yet been rigorously proven. 
Details of the association of I. typographus with specific fungi are not well understood because different associates have been isolated from attacked trees in different geographic areas (Table 1), and the composition of fungi changes in bark beetle galleries during different stages of attack. On the geographical level, Endoconidiophora polonica (Siemaszko) Z.W. de Beer, T.A. Duong \& M.J. Wingf. is reported to be the dominant fungal associate in Norway, Poland, and Austria (Kirisits 2010; Krokene and Solhheim 1996). However, in other regions, Ophiostoma bicolor R.W. Davidson \& D.E. Wells or Grosmannia penicillata (Grosmann) Goid. are reported to be predominant (Linnakoski et al. 2016; Persson et al. 2009; Repe et al. 2013; Viiri and Lieutier 2004). Other ophiostomatoid fungi that have been found in association with I. typographus in several regions include Grosmannia europhioides (E.F. Wright \& Cain) Zipfel, Z.W. de Beer \& M.J. Wingf., Ophiostoma ainoae H. Solheim and Ophiostoma piceae (Münch) Syd \& P. Syd. (Jankowiak et al. 2009; Kirisits 2010; Persson et al. 2009; Repe et al. 2013; Viiri and Lieutier 2004; Yamaoka et al. 1997). The regional distributions of different ophiostomatoid fungi might be due to differences in temperature optima for growth as well as local adaptations to climate, host chemistry, phloem moisture levels, and even investigation methods (Giordano et al. 2013; Linnakoski et al. 2016; Six and Bentz 2007; Solheim 1991b). To clarify the roles of each fungal species in the interaction with I. typographus, comparative studies are needed to determine their abilities to concentrate vital nutrients and detoxify host defense compounds.

In the spruce forests of southern Norway and northeastern Poland, E. polonica is frequently the first ophiostomatoid fungus that establishes in phloem tissues adjacent to the parent gallery because it can grow well under low oxygen and high moisture conditions and thus has a competitive advantage as the primary invader in fresh wood (Kirisits 2010; Solheim 1992). Endoconidiophora polonica also can detoxify host chemical defenses that are induced upon beetle attack, thereby providing an additional benefit to beetle larvae and adults (Wadke et al. 2016). Once I. typographus is established in the tree and E. polonica grows into the sapwood, other fungi such as $O$. bicolor, G. penicillata, and G. europhioides may successively appear in the phloem around the larval galleries (Solheim 1991a, 1992). For example, G. penicillata was shown to be better adapted to grow in the phloem tissues than

Table 1 Bark beetles common in spruce and pine forests in Europe and North America and their associated fungal symbiont

\begin{tabular}{|c|c|c|c|c|c|c|}
\hline Bark beetle & Host tree & Distribution & Associated fungi & $\begin{array}{l}\text { Beetle } \\
\text { transport site }\end{array}$ & $\begin{array}{l}\text { Division and } \\
\text { order }\end{array}$ & Relationship \\
\hline \multirow[t]{2}{*}{$\begin{array}{l}\text { Ips typographus } \\
\text { Eurasian bark } \\
\text { beetle }\end{array}$} & $\begin{array}{l}\text { Mainly Norway } \\
\text { spruce (Picea } \\
\text { abies) }\end{array}$ & Eurasia & $\begin{array}{l}\text { Endoconidiophora } \\
\quad \text { polonica }\end{array}$ & $\begin{array}{l}\text { Exoskeleton, } \\
\text { gut }\end{array}$ & $\begin{array}{l}\text { Ascomycota, } \\
\text { Microascales }\end{array}$ & - \\
\hline & & & $\begin{array}{l}\text { Grosmannia europhioides, } \\
\text { Grosmannia penicillata, } \\
\text { Ophiostoma bicolor, } \\
\text { Ophiostoma ainoae, } \\
\text { Ophiostoma piceae }\end{array}$ & $\begin{array}{l}\text { Exoskeleton, } \\
\text { gut }\end{array}$ & $\begin{array}{l}\text { Ascomycota, } \\
\text { Ophiostomales }\end{array}$ & - \\
\hline \multirow{3}{*}{$\begin{array}{l}\text { Dendroctonus } \\
\text { ponderosae } \\
\text { Mountain pine } \\
\text { beetle }\end{array}$} & All pine trees & North America & Grosmannia clavigera & $\begin{array}{l}\text { Mycangia, } \\
\quad \text { exoskeleton }\end{array}$ & $\begin{array}{l}\text { Ascomycota, } \\
\text { Ophiostomales }\end{array}$ & $\begin{array}{l}\text { Obligate } \\
\text { mutualist }\end{array}$ \\
\hline & & & Ophiostoma montium & $\begin{array}{l}\text { Mycangia, } \\
\text { exoskeleton }\end{array}$ & & $\begin{array}{l}\text { Obligate } \\
\text { mutualist }\end{array}$ \\
\hline & & & $\begin{array}{l}\text { Leptographium } \\
\text { longiclavatum }\end{array}$ & $\begin{array}{l}\text { Mycangia, } \\
\text { exoskeleton }\end{array}$ & & Mutualist \\
\hline \multirow{3}{*}{$\begin{array}{l}\text { Dendroctonus } \\
\text { frontalis } \\
\text { Southern pine } \\
\text { beetle }\end{array}$} & All pine trees & $\begin{array}{l}\text { Southern United } \\
\text { States }\end{array}$ & Entomocorticium sp. A. & Mycangia & $\begin{array}{c}\text { Basidiomycota, } \\
\text { Russulales }\end{array}$ & $\begin{array}{l}\text { Obligate } \\
\text { mutualist }\end{array}$ \\
\hline & & & $\begin{array}{l}\text { Ceratocystiopsis } \\
\text { ranaculosus }\end{array}$ & Mycangia & $\begin{array}{l}\text { Ascomycota, } \\
\text { Ophiostomales }\end{array}$ & Mutualist \\
\hline & & & Ophiostoma minus & Exoskeleton & $\begin{array}{l}\text { Ascomycota, } \\
\text { Ophiostomales }\end{array}$ & Antagonist \\
\hline $\begin{array}{l}\text { Ips pini } \text { Pine } \\
\text { engraver beetle }\end{array}$ & $\begin{array}{l}\text { Mostly weak } \\
\text { and dead pine } \\
\text { trees }\end{array}$ & North America & Ophiostoma ips & Exoskeleton & $\begin{array}{l}\text { Ascomycota, } \\
\text { Ophiostomales }\end{array}$ & $\begin{array}{r}\text { Conditional } \\
\text { mutualist }\end{array}$ \\
\hline $\begin{array}{l}\text { Dendroctonus } \\
\text { rufipennis } \\
\text { North American } \\
\text { spruce beetle }\end{array}$ & $\begin{array}{c}\text { All spruce } \\
\text { species }\end{array}$ & $\begin{array}{l}\text { The Rocky } \\
\text { Mountains } \\
\text { (North America) }\end{array}$ & Leptographium abietinum & Exoskeleton & $\begin{array}{l}\text { Ascomycota, } \\
\text { Ophiostomales }\end{array}$ & $\begin{array}{r}\text { Conditional } \\
\text { mutualist }\end{array}$ \\
\hline
\end{tabular}


in sapwood, and often forms dense lawns of asexual spores in pupal chambers. Endoconidiophora polonica, on the other hand, was reported to occur less frequently during the pupal and adult stages of the beetle (Kirisits 2004).

\section{The North American Spruce Beetle Has a Consistent}

Fungal Partner The North American spruce beetle, Dendroctonus rufipennis Kirby, occurs throughout all spruce (Picea spp.) habitats in North America, and has caused severe forest mortality in the Rocky Mountains in recent years (Hart et al. 2014; Maroja et al. 2007). Like the Eurasian spruce bark beetle, D. rufipennis does not possess glandular mycangia. Despite this, D. rufipennis frequently is associated with Leptographium abietinum (Peck) M.J. Wingf. throughout its range (Six and Bentz 2003) (Table 1). Studies of the fungal populations associated with $D$. rufipennis in nature have shown an 80-100\% incidence of L. abietinum (Aukema et al. 2005; Six and Bentz 2003). Although the in vivo benefit of L. abietinum to D. rufipennis is not completely understood, this fungus produces ergosterol (Bentz and Six 2006), a steroid which is required by many insect species to produce hormones for various developmental processes (Clayton 1964; Mondy and Corio-Costet 2000), However, plants often contain sterols only in low amounts or in forms inaccessible to insects. Therefore, bark beetles that feed on L. abietinum and other fungi may be able to supplement their diet with essential sterols. A recent study showed that $D$. rufipennis feeding under artificial conditions on L. abietinum gained considerably more weight and had higher survival rates compared to beetles feeding on the same diet without L. abietinum. However, the study also showed that the presence of $L$. abietinum negatively affected oviposition and gallery construction by D. rufipennis in vitro (Cardoza et al. 2008). It was, therefore, concluded that the association with L. abietinum may provide nutritional benefits to the beetle, but might also have antagonistic effects.

\section{Pine-Infesting Bark Beetles often Form Symbiotic Relationships with Specific Fungi Dendroctonus} ponderosae Hopkins, the mountain pine beetle, is the most well-studied species of all the conifer colonizing bark beetles. It is indigenous to western North America and primarily attacks lodgepole pine and other pine species (Wood 1982b). Dendroctonus ponderosae mainly vectors fungi such as Grosmannia clavigera (Robinson-Jeffrey \& R.W. Davidson) Zipfel, Z.W. de Beer \& M.J. Wingf., Ophiostoma montium (Rumbold) Arx and Leptographium longiclavatum S.W. Lee, J.J. Kim \& C. Breuil (Table 1) (Six 2012). While G. clavigera is carried predominantly in sac-like mycangia located on the maxillary cardines (a portion of the mouthparts) as well as on the exoskeleton, $O$. montium often is seen in larger numbers on the exoskeleton than in mycangia (Six 2003; Whitney and Farris 1970). The mycangial secretions support the yeast-like cell division of spores, providing a continuous supply of inoculum to $D$. ponderosae for an extended period of time during host colonization (Bleiker et al. 2009).

With its long co-evolutionary history with $D$. ponderosae, $G$. clavigera is reported to be much more aggressive during host colonization compared to O. montium, which is only moderately pathogenic to pine trees (Solheim and Krokene 1998). Grosmannia clavigera tolerates the high levels of monoterpenes in freshly attacked bark by employing specific ATP-binding cassette transporters (ABC) that export monoterpenes from the fungal cell (Wang et al. 2013). This species also can utilize monoterpenes as a carbon source, making it exceptionally well-adapted for survival in resinous bark and wood tissue (Wang et al. 2014).

Dendroctonus ponderosae and its fungi exhibit a mutualistic symbiosis. Both $G$. clavigera and $O$. montium play an essential role in $D$. ponderosae development by concentrating nitrogen and producing ergosterol, which is critical for beetle development and reproduction (Bentz and Six 2006). Grosmannia clavigera concentrates nitrogen better than O. montium, possibly by assimilating it from sapwood and transporting it to the phloem tissues (Bleiker and Six 2007; Cook et al. 2010). Beetles that fed on phloem colonized by G. clavigera emerged faster and produced more offspring with larger body sizes than beetles fed on $O$. montium, which in turn were larger than beetles reared without fungi (Bleiker and Six 2007; Six and Paine 1998). This shows that two mutualist fungi of $D$. ponderosae differ in the scale of the benefits they offer to the beetle and of the two, G. clavigera can be considered superior. Despite this observation, the developing larvae preferentially fed on phloem infested with both fungi over phloem infested with either species alone, indicating complementary benefits (Bleiker and Six 2007). It appears that feeding on spores by newly eclosed, sexually immature (teneral) adult beetles is necessary for reproduction. Teneral adults that fed on spores of mutualistic fungi produced in the pupal chamber consumed little phloem before emerging. In contrast, when spores were not produced in the pupal chamber, teneral adults tunneled extensively into the phloem tissues (Bleiker and Six 2007). Newly emerged adults that failed to feed on spores produced few egg galleries and laid no eggs ( $\mathrm{Six}$ and Paine 1998).

Temperature plays a major role in determining the relative proportions of the two fungi in a given population of D. ponderosae. Grosmannia clavigera dominates at cooler locations with temperature optima around $20{ }^{\circ} \mathrm{C}$, whereas $O$. montium dominates in warmer areas with optimum growth close to $30{ }^{\circ} \mathrm{C}$ (Moore and Six 2015; Six and Bentz 2007). However, during in vitro competition, $G$. clavigera captures more resources at most temperatures compared to $O$. montium (Moore and Six 2015). Interestingly, sporulation of G. clavigera peaked at $30{ }^{\circ} \mathrm{C}$, which is suboptimal for the growth of this fungus, whereas $O$. montium sporulated at 
low levels across all temperatures. As global average temperature is predicted to rise in coming years, a temperature-driven model predicted that in a few decades, $O$. montium may come to dominate this symbiosis (Addison et al. 2013). These studies collectively showed that temperature can differentially affect growth, resource capture, and sporulation of the two mutualistic symbionts in space and time, which in turn could influence the population dynamics of $D$. ponderosae.

The southern pine beetle, Dendroctonus frontalis Zimmermann, is the most destructive bark beetle species within its natural range in the southern United States, attacking healthy pine trees when population levels are high (Ungerer et al. 1999). With its rapid generation time and fast dispersal rate, $D$. frontalis is an economically important pest that causes especially severe damage in regions affected by drought and high temperatures. It has been suggested that a rise of $3{ }^{\circ} \mathrm{C}$ in minimum temperature would allow the $D$. frontalis population to move northwards and expand its natural range to naïve pine forests with no prior evolutionary exposure to this threat (Ungerer et al. 1999). The reproductive success of $D$. frontalis depends mainly on two mutualist fungi, the basidiomycete Entomocorticium sp. A and the non-staining ascomycete Ceratocystiopsis ranaculosus J.R. Bridges \& T.J. Perry, which are carried in the prothoracic mycangia of female beetles (Barras and Perry 1972.; Happ et al. 1971) (Table 1). The developing larvae receive their nutrition by feeding on Entomocorticium sp. A. and C. ranaculosum growing within and adjacent to the feeding tunnels (Barras 1973; Bridges and Perry 1985). The basidiomycete, Entomocorticium sp. A is more beneficial to the bark beetle than the other associate, C. ranaculosum, in terms of both total nitrogen content in the hyphae and in concentrating nitrogen in the phloem. Dendroctonus frontalis that develop together with Entomocorticium sp. A also are larger, with higher lipid content and higher fertility than those that develop with the other associate, C. ranaculosum (Ayres et al. 2000; Coppedge et al. 1995; Goldhammer et al. 1990).

A close relative of $D$. frontalis, Dendroctonus brevicomis LeConte (the western pine beetle), also possesses a similar set of mutualistic symbionts - Entomocorticium sp. B, a basidiomycete and Ceratocystiopsis brevicomis Hsiau \& T.C. Harr., an ascomycete (Bracewell and Six 2014). An experiment to evaluate the dependence and fidelity of $D$. brevicomis towards its symbiotic fungi showed that Entomocorticium sp. B is crucial for successful development of this beetle because beetles reared without this fungus produced no offspring. Furthermore, this experiment showed that beetle fitness did not vary when grown together with natal (isolated from same beetle population used in the study) and non-natal (genetically distinct isolate from geographically distinct beetle population) fungal isolates. Interestingly, emerging adults incorporated only the natal isolate into the mycangium and avoided the non-natal isolate (Bracewell and Six 2015).
Not all ophiostomatoid fungi are mutualists or commensals of their associated beetles. For example, the blue-stain fungus Ophiostoma minus (Hedgcock) Syd. \& P. Syd., which is often encountered in larval galleries of $D$. frontalis, is a strong antagonist to this beetle. Ophiostoma minus is a mutualist of phoretic mites (commensal organisms which use beetles as a means of transport) that feed on this fungus and reproduce faster in its presence. Beetle larvae that fed on the portion of the phloem colonized by $O$. minus avoided this fungus by making long tunnels but eventually died (Barras 1970; Hofstetter et al. 2006a). The exact mechanism of antagonism is not known, but production of bioactive polyphenols by $O$. minus may explain avoidance by $D$. frontalis. (Hemingway et al. 1977). Ophiostoma minus also was reported to grow faster than the two mutualistic Southern pine beetle fungi by capturing more resources, which was shown to have a strong influence on beetle population dynamics (Hofstetter et al. 2006a, b).

The pine engraver beetle, Ips pini (Say) is a native species widely distributed in North America which preferentially attacks stressed, wind-blown, and dead mature pine trees of all species within its geographic range. Ophiostoma ips (Rumbold) Nannf., the most dominant fungal associate of this species, is carried in pit-like mycangia on the exoskeleton of this bark beetle (Furniss et al. 1995) (Table 1). This fungus is a generalist, sap-staining pathogenic fungal associate of other conifer-infesting bark beetles as well, occurring in many parts of the world (Suh et al. 2013;Zhou et al. 2002). Ophiostoma ips has both positive and negative effects on I. pini, and the effects vary based on the timing of fungal establishment. For example, when O.ips was introduced in logs before the beetle, there was a reduction in the entry of females, but the presence of $O$. ips in larval galleries increased brood emergence. However, when both fungus and beetle were introduced at the same time, there was no noticeable difference in brood development and adult emergence (Kopper et al. 2004; Yearian et al. 1972). This study indicated that I. pini might use volatile cues arising from its symbiotic fungus to evaluate the extent of host colonization by conspecific beetles, thus avoiding crowding (Kopper et al. 2004).

\section{Volatiles from ophiostomatoid Fungi and their Effects on Bark Beetles}

Fungi often emit complex mixtures of various low molecular weight compounds with a distinctive odor. These volatile organic compounds have been studied for many years in the food and flavor industries, and even serve as biomarkers for identification of harmful molds in agriculture and fungal infestations in buildings. The volatile blend produced by a fungus varies with respect to growth conditions such as temperature, substrate, and time. Additionally, different genotypes 
within the same or sympatric species exhibit both qualitative and quantitative differences in their profiles of volatiles (Mburu et al. 2013; Weikl et al. 2016).

Fungal volatiles are known to facilitate many of the associations between fungi and insects, acting as pheromones, kairomones, and allomones. However, the volatiles emitted by the fungal partners of bark beetles have received little study. Thus, we collected volatiles from ten species of beetle-associated, ophiostomatoid fungi grown in potato dextrose broth and searched the literature for the effects of these de novo synthesized volatiles on bark beetles. The results are given in Table 2 and described in the following sections. To determine if the volatiles emitted when fungi are grown in potato dextrose broth are similar to those emitted under natural conditions, we compared the emission profiles of several I. typographus-associated fungi, including E. polonica, O. bicolor, O. piceae, G. europhioides, and G. penicillata, grown on potato dextrose broth (Supplemental material) with the emission profiles when grown on spruce bark. There were few qualitative or quantitative differences between these two types of media for most species, indicating that the volatiles we detected from fungi grown on potato dextrose broth are likely to be emitted under natural conditions.

Fusel Alcohols and their Acetates Fusel alcohols are low molecular weight aliphatic and aromatic alcohols produced by degradation of amino acids via the Ehrlich pathway (Hazelwood et al. 2008). The Ehrlich pathway involves a transamination step in which the amino group is exchanged for an oxygen, resulting in an $\alpha$-keto acid. Decarboxylation then forms an aldehyde, which then can be reduced to a fusel alcohol by an alcohol dehydrogenase. These alcohols, derived mainly from phenylalanine, valine, leucine, isoleucine, and methionine, can be further modified by esterification of the alcohols to form acetates with strong odors (Pires et al. 2014) that are extensively utilized in the food and flavor industries.

Fusel alcohols are produced mainly by fungi, and the aromas of these compounds attract many fungivorous insects such as nitilulid beetles and fruit flies, which disperse the emitting microbes to new colonization sites (Bartlet and Wicklow 1999; Christianens et al. 2014). Fusel alcohols (e.g., isoamyl alcohol and 2-phenylethanol, Fig. 1) and their acetate esters (isoamyl acetate and 2-phenylethyl acetate), were produced by several species of Ophiostoma, Ceratocystis, Grosmannia, and Endoconidiophora in our collections (Table 2) with the rate of emission varying among species. These compounds may play a role in bark beetleophiostomatoid fungus associations by attracting beetles to their symbionts, or to symbiont habitats. Although fungal symbionts are expected to be present already in beetle galleries during initial attack on the host tree, volatiles may keep beetle feeding closely synchronized with areas of fungal growth, thus allowing beetles to maximize the benefits from this association. In theory, fungal volatiles could also repel beetles by signaling host trees or areas of host trees that are already under attack by competing beetles. However, published data mostly report attraction of beetles to specific fungal volatiles rather than repulsion. For example, isoamyl acetate and 2-phenylethyl acetate have been reported to attract $D$. frontalis in laboratory assays when added to unattractive concentrations of pheromone blends, either separately or together (Brand et al. 1977). Additionally, isoamyl alcohol and 2-phenylethanol together with their acetates efficiently synergized the attractiveness of bait mixtures used to capture D. frontalis (Brand et al. 1977). On the other hand, 2phenylethanol was shown to be a strong anti-aggregation component for $D$. ponderosae and $D$. frontalis when added to their pheromone blends (Pureswaran et al. 2000; Sullivan et al. 2007). 2-Phenylethanol also was found in hindgut extracts of I. typographus and I. pini, and elicited strong antennal responses from both sexes, but addition of 2-phenylethanol to the respective pheromone blends of these beetle species did not significantly alter attraction (Borden et al. 1998; Pureswaran et al. 2000; Schlyter et al. 1987). The role of fusel alcohols in the attraction of other bark beetle species is unknown.

Aliphatic Alcohols Aliphatic alcohols are produced via the oxidation and cleavage of polyunsaturated fatty acids such as linoleic acid. Although the exact pathways in fungi still need to be elucidated, it is known that biosynthesis first involves oxidation of fatty acids by enzymes such as lipoxygenases or fatty acid diol synthases. The resultant hydroperoxide intermediates are cleaved by hydroperoxide lyases using a hemolytic cleavage mechanism to form short- or medium-chain aliphatic alcohols (Combet et al. 2006).

1-Hexanol Bark beetles have been shown to reject non-host tree species due to the absence of host cues or the presence of non-host volatiles. 1-Hexanol (Fig. 1) is a green leaf volatile (GLV), one of a group of $\mathrm{C}_{6}$ alcohols, aldehydes, and esters emitted by the foliage of many angiosperms. We found that ophiostomatoid fungi such as $G$. europhioides, $O$. bicolor, $O$. piceae, and $O$. minus also produce 1-hexanol when cultivated in the laboratory (Table 2). The compound has been described to be a synergistic repellent (a compound that repels only in combination with other compounds, but not by itself) for I. typographus, D. ponderosae, and D. frontalis (Borden et al. 1998; Dickens et al. 1992; Zhang et al. 1999). Additionally, 1-hexanol is the only known GLV that disrupts D. rufipennis attraction to its pheromone blend (Poland et al. 1998). Ips pini, on the other hand, showed no behavioral response to 1-hexanol and other GLVs, although the GLVs hexanal and $(E)$-2-hexenal elicited strong antennal responses from this species (Huber et al. 2001). 
Table 2 List of some fungal volatiles identified from ophiostomatoid fungi as detected in our collections. Only selected volatiles are listed emphasizing compounds previously shown to have activity with bark beetles. Fungi were grown in potato dextrose broth, headspace volatiles collected on sorbent, and compounds analyzed by thermal desorption-gas chromatography-mass spectrometry (more information given in supplemental section). Bark beetles reported to respond to these volatiles and the behavioral significance of these volatiles for the beetles are also listed

\begin{tabular}{|c|c|c|c|c|}
\hline Fungal volatile & $\begin{array}{l}\text { Emitting ophiostomatoid } \\
\text { species }\end{array}$ & $\begin{array}{l}\text { Responding bark } \\
\text { beetle species }\end{array}$ & $\begin{array}{l}\text { Behavioral response of } \\
\text { beetle }\end{array}$ & References \\
\hline \multicolumn{5}{|l|}{ Fusel alcohols and acetates } \\
\hline Isoamyl alcohol & $\begin{array}{l}\text { E. polonica, G. clavigera, } G . \\
\text { penicillata, G. europhioides, } \\
\text { O. bicolor, O. piceae, } O . \\
\text { minus, O. ips, L. abietinum }\end{array}$ & D. frontalis & Synergist of attractant & (Brand et al. 1977) \\
\hline Isoamyl acetate & $\begin{array}{l}\text { E. polonica, G. penicillata, } G \text {. } \\
\text { europhioides, } O \text {. bicolor, } O \text {. } \\
\text { piceae, O. minus, }\end{array}$ & D. frontalis & Synergist of attractant & (Brand et al. 1977) \\
\hline \multirow[t]{3}{*}{ 2-Phenylethanol } & \multirow{3}{*}{$\begin{array}{l}\text { E. polonica, G. clavigera, } G . \\
\text { penicillata, G. europhioides, } \\
\text { O. bicolor, O. piceae, } O . \\
\text { minus, O. ips, L. abietinum }\end{array}$} & D. frontalis & Anti-aggregant & (Sullivan et al. 2007) \\
\hline & & D. ponderosae & Anti-aggregant & (Pureswaran et al. 2000) \\
\hline & & $\begin{array}{l}\text { I. typographus, } I \text {. } \\
\text { pini }\end{array}$ & No response & $\begin{array}{l}\text { (Borden et al. 2004; Schlyter } \\
\text { et al. 1987) }\end{array}$ \\
\hline 2-Phenylethyl acetate & $\begin{array}{l}\text { E. polonica, G. penicillata, } G \text {. } \\
\text { europhioides }\end{array}$ & D. frontalis & Synergist of attractant & (Brand et al. 1977) \\
\hline \multicolumn{5}{|l|}{ Aliphatic alcohols } \\
\hline \multirow[t]{3}{*}{ 1-Hexanol } & \multirow[t]{3}{*}{$\begin{array}{l}\text { G. europhioides, } O \text {. bicolor, } O \text {. } \\
\quad \text { piceae, O. minus }\end{array}$} & $\begin{array}{l}\text { I. typographus, } D . \\
\text { ponderosae, } D \text {. } \\
\text { frontalis }\end{array}$ & Synergist of repellent & $\begin{array}{l}\text { (Borden et al. 1998; Dickens } \\
\text { et al. 1992; Zhang et al. 1999) }\end{array}$ \\
\hline & & D. rufipennis & Anti-aggregant & (Poland et al. 1998) \\
\hline & & I. pini & No response & (Huber et al. 2001) \\
\hline 1-Octanol & $\begin{array}{l}\text { O. piceae, } O \text {. minus, } L \text {. } \\
\text { abietinum }\end{array}$ & - & - & \\
\hline 1-Nonanol & $\begin{array}{l}\text { O. piceae, } O \text {. minus, } L \text {. } \\
\text { abietinum }\end{array}$ & - & - & \\
\hline \multicolumn{5}{|l|}{ Aromatic compounds } \\
\hline Benzyl alcohol & G. penicillata, O. piceae, O. ips & $\begin{array}{l}\text { D. ponderosae, } I \text {. } \\
\text { pini, D. rufipennis, } \\
\text { D. brevicomis }\end{array}$ & Synergist of anti-aggregant & $\begin{array}{l}\text { (Borden et al. 1998; Huber } \\
\text { et al. 2001) }\end{array}$ \\
\hline Methyl cinnamate & O. ips & - & - & \\
\hline Ethyl cinnamate & O. ips & - & - & \\
\hline Ethyl benzoate & O. ips & - & - & \\
\hline \multirow[t]{2}{*}{ Acetophenone } & \multirow[t]{2}{*}{ O. ips } & $\begin{array}{l}\text { D. ponderosae, I. } \\
\text { pini, D. rufipennis }\end{array}$ & No response & $\begin{array}{l}\text { (Pureswaran and Borden 2004; } \\
\text { Pureswaran et al. 2000) }\end{array}$ \\
\hline & & $\begin{array}{l}\text { D. brevicomis, } D \text {. } \\
\text { pseudotsugae, } D \text {. } \\
\text { frontalis, }\end{array}$ & Anti-aggregant & $\begin{array}{l}\text { (Erbilgin et al. 2008; Pureswaran } \\
\text { and Borden 2004) }\end{array}$ \\
\hline 2,3-Dihydrobenzofuran & O. ips & - & - & \\
\hline \multicolumn{5}{|l|}{ Terpenoids } \\
\hline \multirow[t]{2}{*}{ Geranyl acetone } & \multirow{2}{*}{$\begin{array}{l}\text { E. polonica, } O . \text { bicolor, } G \text {. } \\
\quad \text { clavigera }\end{array}$} & Ips subelongatus & Anti-aggregant & (Zhang et al. 2007) \\
\hline & & $\begin{array}{l}\text { Tetropium fuscum } \\
\text { (Cerambycid } \\
\text { beetle) }\end{array}$ & Pheromone precursor & (Mayo et al. 2013) \\
\hline \multirow[t]{2}{*}{ (E)- $\beta$-Caryophyllene } & \multirow[t]{2}{*}{ G. penicillata } & $\begin{array}{l}\text { Pityogenes } \\
\quad \text { bidentatus }\end{array}$ & Synergist of anti-aggregant & (Byers et al. 2004) \\
\hline & & D. armandi & Synergist of attractant & (Zhang et al. 2010) \\
\hline
\end{tabular}

1-Octanol and 1-Nonanol Ophiostoma piceae, O. minus, and L. abietinum emitted 1-octanol and 1-nonanol in our collections (Fig. 1, Table 2). While it is not known whether these compounds elicit electrophysiological and/or behavioral responses from conifer-infesting bark beetles, aliphatic alcohols are reported to attract insect parasitic nematodes (Nematoda: 
Bark beetle pheromones<smiles>CC1=CC(O)C2CC1C2</smiles>

(-)-Verbenol<smiles>CC1=CC2CC1C2C</smiles>

(-)-Verbenone

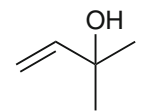

2-Methyl-3buten-2-ol<smiles>CC(C)CCO</smiles>

Isoamyl alcohol<smiles>OCCc1ccccc1</smiles>

2-Phenylethanol<smiles>CC(=O)OCCC(C)C</smiles>

Isoamyl acetate<smiles>CC(=O)OCCc1ccccc1</smiles>

2-Phenylethyl acetate

3-Methyl-2-cyclohexene
-1-ol 3-Methyl-2-cyclohexene

Aliphatic alcohols<smiles>CCCCCCO</smiles>

\section{Aromatic compounds}<smiles>OCc1ccccc1</smiles>

Benzyl alcohol<smiles>CCC(=O)c1ccccc1</smiles>

Acetophenone

2,3-Dihydrobenzofuran<smiles>COC(=O)/C=C/c1ccccc1</smiles>

Methyl (E)-cinnamate<smiles>CCOC(=O)/C=C/c1ccccc1</smiles>

Ethyl $(E)$-cinnamate

\section{Terpenoids}<smiles>CC(=O)CC/C=C(/C)CCC=C(C)C</smiles>

Geranyl acetone

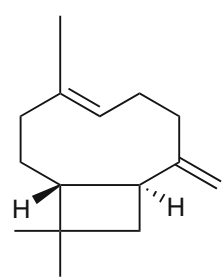

(E)- $\beta$-Caryophyllene

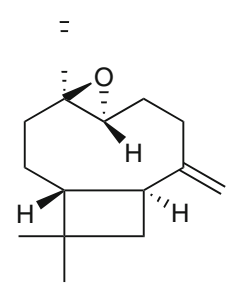

(E)- $\beta$-Caryophyllene oxide

Fig. 1 Chemical structures of bark beetle pheromones and major volatiles emitted by ophiostomatoid fungal associates of conifer bark beetles

Rhabditidae) that feed on bark beetle-associated microbes (O'Halloran and Burnell 2003). In addition, a number of nematode species have been cultured on ophiostomatoid fungi. For example, some species of nematodes associated with D. rufipennis were successfully cultured and maintained on L. abietinum (Cardoza et al. 2008), while a parasitic nematode, Parasitorhabditis sp., isolated from different body parts of the red turpentine beetle, Dendroctonus valens, was maintained and reproduced on sporulating cultures of $O$. minus (Hunt and Poinar 1971). Similarly, O. minus was shown to support the growth of the pathogenic pinewood nematode, Bursaphelenchus xylophilus (Steiner \& Buhrer) Nickle (Maehara and Futai 1997). It is not yet known if fungi such as $O$. minus and L. abietinum actually attract phoretic nematode species (those carried by other organisms) in nature, if fungi are vectored by nematodes, and what effect phoretic nematodes have on bark beetles, but fungal volatiles could conceivably play a role in these interactions.

Sesquiterpenes Sesquiterpenes are produced by fungi from the mevalonate pathway intermediates dimethylallyl diphosphate and isopentenyl diphosphate, which are condensed to produce the $\mathrm{C}_{15}$ farnesyl diphosphate. This linear polyprenyl diphosphate then is further transformed to linear and cyclic products by terpene synthase enzymes. Further modifications of these products via oxidation reactions mediated by cytochrome $\mathrm{P} 450$ enzymes are common in nature, but such reactions have not yet been described in fungi, only in other microbes and higher plants (Keller et al. 2005).

Geranylacetone Produced by the oxidation of the sesquiterpene alcohols farnesol or nerolidol (Mayo et al. 2013), 
geranylacetone (Fig. 1) was detected from three blue stain fungi, E. polonica, G. clavigera, and O. bicolor in our collections (Table 2). The Asian larch bark beetle, Ips subelongatus Motschulsky, demonstrated strong antennal responses to geranylacetone, and this compound significantly disrupted the attractiveness of pheromone mixtures in field experiments (Zhang et al. 2007). Antennae of I. typographus also have been reported to respond to geranylacetone, but it is not known whether this compound mediates the behavior and ecology of I. typographus and most other bark beetle species. However, cerambycid beetles such as the brown spruce longhorn beetle, Tetropium fuscum (Fabricius), and the eastern larch borer, T. cinnamopterum Kirby, utilize geranylacetone as a precursor to their aggregation pheromone, fuscumol, the alcohol analog of geranylacetone (Mayo et al. 2013). Ophiostomatoid fungi producing this compound might, therefore, be attractive to these secondary beetles.

(E)- $\beta$-Caryophyllene The bicyclic sesquiterpene, $(-)-(E)-\beta$ caryophyllene $(=(-)-\beta$-caryophyllene, Fig. 1$)$ is produced by several fungi mostly in their later growth phases (Kramer and Abraham 2012). The generalist ophiostomatoid fungus, G. penicillata, emitted this compound and its epoxide, caryophyllene oxide, in our volatile collections (Table 2). The significance of $(E)$ - $\beta$-caryophyllene and caryophyllene oxide in fungi is not well understood, but these compounds have been reported to have both repellent and anti-fungal properties (Boulogne et al. 2012). For example, the leaves of the legume Hymenaea courbaril L. in Costa Rica, which is seldom foraged on by the leaf-cutting ant Atta cephalotes L., contain both $(E)-\beta$-caryophyllene and caryophyllene oxide. Performance assays indicated that leaf cutting ants avoided caryophyllene oxide more than $(E)$ - $\beta$-caryophyllene, and preferred plants became repellent when treated with these compounds. Additionally, these compounds were reported to have anti-fungal activity against the obligate mutualist fungus farmed by the ants in their nests (Hubbell et al. 1983). Given the repellency and anti-fungal activity of these sesquiterpenes, ophiostomatoid fungi that produce these compounds may be repellent to beetles or able to inhibit the growth of competing microbes. For example, $(E)$ - $\beta$-caryophyllene was reported to disrupt the attraction of Pityogenes bidentatus (Herbst), a small bark beetle that colonizes diseased or weakened branches of Scots pine, Pinus sylvestris L., to its aggregation pheromone (Byres et al. 2004). On the other hand, increased numbers of Dendroctonus armandi Tsai \& Li, a serious pest of Chinese white pine, Pinus armandii Franch., were captured when $(E)$ - $\beta$-caryophyllene was present in combination with other host semiochemicals such as $\alpha$-pinene (Zhang et al. 2010). Other research on $(E)$ - $\beta$-caryophyllene showed that when this compound was produced by certain maize lines, entomopathogenic nematodes that prey on maize root herbivores, such as Heterorhabditis megidis Poinar, Jackson \&
Klein, were recruited (Rasmann et al. 2005). The recruitment of nematodes by $(E)$ - $\beta$-caryophyllene-producing ophiostomatoid fungi may have important consequences for their associated bark beetle species.

Aromatic Compounds Although little is known about the biosynthesis of volatile aromatic compounds in fungi, carbon-labelling studies showed that the formation of phenylpropanoid-derived substances is similar to that in plants proceeding from the amino acid L-phenylalanine, itself a product of the shikimate pathway (Lapadatescu et al. 2000). In the first step, phenylalanine is deaminated to form cinnamic acid, which forms the basic backbone of all aromatic VOCs. This structure can be further modified by methylation, esterification, chain shortening, reduction, oxidation, or chain cyclization (Widhalm and Dudareva 2015). Other aromatic compounds are derived from the polyketide pathway or other intermediates of amino metabolism and the shikimate pathway.

Benzyl Alcohol Grosmannia penicillata, O. piceae, and O. ips emitted benzyl alcohol in our collections (Fig. 1) (Table 2), a compound that also is found in some non-host angiosperms, such as Populus tremula L. Benzyl alcohol was reported to elicit antennal responses from $D$. ponderosae, I. pini, D. rufipennis, and D. brevicomis (Huber et al. 2000). Benzyl alcohol is a non-host volatile that disrupts aggregation of $D$. ponderosae in ternary and quaternary blends with GLVs and other non-host compounds (Borden et al. 1998). Similar behavioral activity was observed in I. pini and the Douglas-fir beetle, Dendroctonus pseudotsugae Hopkins (Huber et al. 2001). Ips typographus, however, displayed no antennal or behavioral response to benzyl alcohol (Zhang et al. 2000).

Acetophenone The aromatic ketone acetophenone (Fig. 1) was emitted only by Ophiostoma ips in our collections, and has not been reported previously from any ophiostomatoid fungus. However, this compound has been detected in several species of bark beetles. Acetophenone was identified in hindgut extracts or odors of $D$. ponderosae, D. rufipennis, D. pseudotsugae, I. pini, D. frontalis, and D. brevicomis (Erbilgin et al. 2007; Pureswaran and Borden 2004; Pureswaran et al. 2000; Sullivan 2005). It has been reported to be a strong anti-aggregant for the western pine beetle, D. brevicomis, and even is superior to verbenone as a repellent (Erbilgin et al. 2008). Interestingly, acetophenone did not inhibit the attraction of the western pine beetle predator, Temnochila chlorodia (Mannerheim) (Coleoptera: Trogositidae), to beetle aggregation pheromones, thus resulting in a high predator to prey ratio in baited traps, whereas verbenone added to this lure inhibited predator attraction to western pine beetle (Erbilgin et al. 2008). Attraction of D. frontalis to its pheromone blend also is inhibited by 
addition of acetophenone, and a similar effect was reported for D. pseudotsugae (Pureswaran and Borden 2004). On the other hand, acetophenone showed no behavioral effect on D. ponderosae, I. pini, and D. rufipennis, but did elicit antennal responses in both sexes of $D$. ponderosae and I. pini (Pureswaran et al. 2000). Because the acetophenoneproducing $O$. ips is a fungal symbiont of $I$. pini, it may be fitting that this compound has no behavioral effect on I. pini, but repels other bark beetles.

2, 3-Dihydrobenzofuran Also known as coumaran, 2,3dihydrobenzofuran and its derivatives (Fig. 1) have been widely reported as anti-feedants or insecticides for many polyphagous insects (Morimoto et al. 1999b). This compound is a natural fumigant, and the most common secondary metabolite of plants in the family Cyperaceae, which includes many common wetland weeds (Morimoto et al. 1999a). Its insecticidal properties are attributed to its ability to inhibit acetylcholinesterase, which degrades the neurotransmitter acetylcholine. Inhibition of this enzyme results in excessive buildup of the neurotransmitter at the synaptic junctions, which causes prolonged neural excitation and ultimately leads to death (Rajashekar et al. 2014). 2,3-Dihydrobenzofuran occurred in our volatile collections from $O$. ips cultures under laboratory conditions (Table 2); this is the first report of the identification of such a fumigant from a fungus. Its activity as a volatile insecticide and anti-feedant suggests potential for utilization in bark beetle management.

Methyl and Ethyl (E)-Cinnamate The volatile aromatic esters, methyl and ethyl cinnamate (Fig. 1) may participate in complex interactions among fungi, beetles, host trees, and nematodes. These compounds are known to have strong nematicidal activity even at low concentrations against the pinewood nematode, B. xylophilus, the causal agent of pine wilt disease (Kim et al. 2011). Longhorn beetles in the genus Monochamus, which are widely distributed across pine forests globally, are important vectors of the pinewood nematode (Akbulut and Stamps 2012). Some longhorn beetle species also vector ophiostomatoid fungi such as $O$. minus and $O$. ips along with the pinewood nematode. These nematodes utilize ophiostomatoid fungi as nutrient sources and the presence of $O$. minus in beetle galleries increases the number of nematodes carried by emerging beetles (Maehara and Futai 1997). However, the nutritional advantage of $O$. ips to the pinewood nematode and its beetle vector is not known. Methyl and ethyl cinnamate were the predominant volatiles emitted from $O$. ips cultures in our collections (Table 2), and the growth of nematicide-producing $O$. ips in pine could be detrimental to pinewood nematodes. Further experiments on the performance of pinewood nematodes in the presence of $O$. ips could give more insights into the role of fungal volatiles in the population dynamics of the nematodes as well as their beetle vectors. In support of the hypothesis that $O$. ips may negatively affect both beetle and nematode populations, the edible fruiting bodies of Tricholoma matsutake, which emit high concentrations of methyl cinnamate, deter the mycophagous hexapod, Proisotoma minuta (Tullberg) (Collembola: Isotomidae) from feeding on their fruiting bodies (Sawahata et al. 2008).

Use of Fungal Volatiles by Bark Beetle Predators Some natural enemies of bark beetles have been shown to locate their prey through volatiles emitted by beetle-associated symbiotic fungi. For example, females of the pteromalid wasps, Roptrocerus xylophagorum (Ratzeburg) and Spathius pallidus Ashmead, the most common parasitoids of bark beetles in North America, were attracted to volatiles of $O$. ips- and O. minus-inoculated pine bolts in olfactometer assays (Sullivan and Berisford 2004). However, in field assays with O. minus-inoculated and mock-inoculated bolts, there was no significant difference in attraction to the two treatments. Nevertheless, female $R$. xylophagorum were not attracted to beetle larval or pupal stages alone, but were attracted only to bark colonized by beetles and containing larval feces (Sullivan and Berisford 2004), suggesting a role for fungal associates in providing attractive stimuli. Another study showed that the specialist parasitoids, Heydenia unica Cook \& Davis and Rhopalicus pulchripennis Crawford, which prey on late larval instars of bark beetles, exploit volatiles from $O$. ips, G. clavigera, and O. montium as attractants, whereas generalist predators and parasitoids mainly use host pheromones and plant volatiles to locate their hosts (Adams and Six 2008; Boone et al. 2008). Other bark beetle parasitoids also may be attracted by the volatiles of beetle-associated fungi. Studies on I. typographus-infested Norway spruce bolts showed emission of several oxygenated terpenes and other volatiles that are typically produced by bark beetleassociated microbes or by auto-oxidation of tree resins. A synthetic blend of oxygenated terpenes was found to elicit olfactory responses in chalcid wasps and to be very attractive to these wasps in laboratory bioassays (Pettersson 2001; Pettersson and Boland 2003).

Oxidation Products of Host Tree Terpenes The fungal volatile compounds discussed until now are all likely to be synthesized de novo by associates of bark beetles since they were detected when fungi were cultured solely on potato dextrose broth. However, fungal volatiles also could be produced by the metabolism of host plant substances. Many plant pathogenic fungi are reported to transform terpene olefins to oxygenated metabolites in vitro, such as the well-known horticultural pathogens Botrytis cinerea Persoon, Aspergillus niger Tieghem, and Penicillium digitatum (Persoon) Sacc. Among the ophiostomatoid fungi, $G$. clavigera transforms the hostderived monoterpene limonene to the volatile oxygenated 
metabolites, carvone, $p$-mentha-2,8-dienol, perillyl alcohol, and isopiperitenol in vitro (Wang et al. 2014). This fungus utilizes limonene as a carbon source (DiGuistini et al. 2011; Wang et al. 2013) for growth. Other mountain pine beetleassociated fungi also can use limonene as a carbon source (Wang et al. 2014), and so also may produce volatile oxygenated metabolites of this monoterpene. Because oxygenated monoterpenes have been shown experimentally to attract parasitoids of bark beetles (Pettersson 2001), fungal transformation products of limonene may function as kairomones for natural enemies, and thus negatively impact bark beetle fitness.

The fungal transformation products that have received the greatest attention are those identical to the pheromones produced by bark beetles. For example, a number of yeast species found in I. typographus guts or on their exoskeleton, e.g., Hansenula and Candida spp., convert the aggregation pheromone components (-)-cis-verbenol and (-)-trans-verbenol to (-)-verbenone (Fig. 1). The oxidized monoterpene (-)verbenone inhibits beetle aggregation (Leufven et al. 1984). The precursor verbenols are themselves transformation products, being made from host tree monoterpenes by beetles (Hughes 1973). Similarly, C. ranaculosum, the mycangial fungal associate of the southern pine beetle $D$. frontalis, has been shown to convert (-)-trans-verbenol to (-)-verbenone and 3-methyl-2-cyclohexen-1-ol to its corresponding ketone, 3-methyl-2-cyclohexen-1-one (Fig. 1). Both ketones are known anti-aggregation pheromone components of several Dendroctonus species (Brand et al. 1976). Recently, two fungal symbionts of I. typographus, G. europhioides and G. penicillata, were shown to produce the major I. typographus aggregation pheromone, 2-methyl-3-buten-2ol (Fig. 1) (Zhao et al. 2015). These examples highlight the important roles that fungal metabolites could play in bark beetle ecology.

\section{Ophiostomatoid Fungal Volatiles in the Management of Bark Beetle Pests}

Integrated pest management of aggressive bark beetle species usually aims to reduce attack on healthy trees when attack severity reaches economic threshold levels. Several practices are commonly employed, such as removal of wind-thrown and infested trees and thinning of conifer stands. However, accessibility to remote areas and economic and environmental constraints often hamper quick removal of large numbers of infested trees (Christiansen and Bakke 1988). Usage of insecticides that specifically target beetle species is another straightforward control strategy that can cause severe mortality to broods at the site of treatment (Grosman et al. 2009). However, insecticides can play at most a relatively small role in managing major outbreaks due to the logistics and economics of applying insecticides over large, remote forested areas. Additionally, the choice of insecticides may have serious ecological implications due to non-target effects, and their usage may be limited by local legislation. Trap trees were successfully used in the past to limit attacks by baiting a cut tree or healthy trees with pheromones or pheromones and insecticides in order to divert beetles from attacking healthy trees. However, the trap tree must be removed from the forest in time to avoid the risk of spill-over infestations to nearby non-baited trees which could quickly lead to outbreaks (Hokkanen 1991). Trap trees treated with insecticides are still in use for small scale infestations because these allow enough time for removal without risking further infestation (El-Sayed et al. 2009).

The management of bark beetle populations with pheromones and other semiochemicals is a "green" alternative to the use of synthetic insecticides. Semiochemicals have been extensively employed to monitor beetle population levels and sometimes to trap beetles to keep their population below the threshold at which they attack healthy trees. However, trapping efforts have been limited in scale and area because of logistical and economic limitations. Both attraction ("pull") and deterrence ("push") strategies have been used. The pull strategy employs stimuli such as aggregation pheromones, host volatiles, or visual cues that are either presented alone or combined in specific combinations. This method can be useful for mass trapping of bark beetles, monitoring local beetle populations, or screening for the presence and abundance of exotic beetles that are accidentally introduced (Bakke 1991; Borden 1989). The disadvantages of a pull strategy are the potential of spill-over infestation and the accidental trapping of useful natural enemies that are attracted to pheromones of bark beetles. The push strategy makes use of stimuli that are repellent to beetles and deters them from attacking potential host trees, or from mating and oviposition. Deterrent compounds such as the anti-aggregation pheromone, verbenone, and non-host volatiles (1-hexanol, (Z)-3-hexen-1-ol, and (E)-2-hexen-1-ol, trans-conophthorin, 3-octanol, 1-octen-3-ol) have been tested in field experiments to determine their efficiency (Zhang et al. 1999). For example, aerial application of verbenone- releasing flakes and verbenone bubble caps was shown to significantly reduce the attack rate of mountain pine beetle in pine stands (Gillette et al. 2006; Shea et al. 1992). Combined application of verbenone and non-host volatiles in spruce forests in Sweden and Slovakia was shown to act synergistically, inhibiting or delaying the attack of I. typographus in the treatment areas (Schiebe et al. 2011). However, the push strategy cannot be used as a stand-alone method due to the fact that the repelled beetle population could be diverted to unprotected adjacent areas; therefore it has to be combined with other methods for long term management. 
The combination of push and pull stimuli, commonly referred as the "push-pull strategy" (Cook et al. 2006) also is used to control bark beetles. Pest beetles are deterred by using push stimuli placed within target stands or on their perimeter, and simultaneously attracted by using stimuli attached to baited traps placed outside the target stand. Stimuli can be delivered in a number of ways in this strategy, as described above, and push-pull methods have been successfully tested against the mountain pine beetle, D. ponderosae and Ips paraconfusus Lanier attacking Torrey pine (Pinus torreyana), an endangered species growing in a limited area of California (Gillette et al. 2012; Shea and Neustein 1995). The choice of traps (baited trees or baited traps), plot size, and trap spacing was shown to influence the method's efficacy (Borden et al. 2006).

Possible Applications of Fungal Volatiles Bark beetle infestations also might be managed by exploiting volatiles released by bark beetle-associated fungi. For this review, we screened a number of ophiostomatoid fungal species for volatile metabolites and identified a wide range of organic compounds that might mediate behaviors of bark beetles, and that could be investigated for bark beetle control. However, in order to best utilize these compounds as next-generation semiochemicals, their emission patterns and the behavioral ecology of the beetle species themselves should be studied in more detail.

Bark Beetle Management Fungal volatiles might be especially useful in push-pull strategies where they could synergize the effects of other attractant or repellent components. For example, isoamyl acetate and phenylethyl acetate (Table 2) could be used in combination with a pheromone mix for attracting higher numbers of D. frontalis (Brand et al. 1977). Conversely, the natural anti-feedant volatiles produced by the generalist fungus $O$. ips, including 2,3-dihydrobenzofuran and various cinnamic acid derivatives (Table 2, Morimoto et al. 1999 b), could augment anti-aggregation mixtures for improved efficiency in deterring a wide range of pine-infesting bark beetles. Acetophenone, produced by O. ips (Table 2), already has been reported to strongly repel some Dendroctonus species (Erbilgin et al. 2008; Pureswaran and Borden 2004). For the Eurasian spruce bark beetle, I. typographus, volatiles from its associated fungus E. polonica, such as isoamyl alcohol and 2-phenylethanol (Table 2), also might be useful attractants or repellents. Furthermore, the profiles of volatiles produced by $G$. penicillata and $G$. europhioides contain sesquiterpenes like $(E)$ - $\beta$-caryophyllene (Table 2 ) that may be insecticidal or support the growth of entomopathogenic nematodes. Finally, the profile of volatiles produced by L. abietinum contains aliphatic alcohols (Table 2), which attract predatory nematodes, and could be used for this purpose. It already has been shown that several species of nematodes associated with D. rufipennis can be reared on L. abietinum cell cultures (Cardoza et al. 2008).
Fungal volatiles released from trees that are already infested by conspecifics may repel newly arriving beetles (Cardoza et al. 2008; Kopper et al. 2004). At the same time, these volatiles, in synergy with oxygenated terpenes, might serve as kairomones for natural enemies. Several oxygenated terpenes, such as camphor, pinocamphone, and terpinen-4-ol have been shown to attract parasitoids of bark beetles (Pettersson 2001; Pettersson and Boland 2003). Dispensers with fungal volatiles and oxygenated monoterpenes might, therefore, be used for repelling beetles from potential attack areas such as drought-stressed stands, while simultaneously attracting bark beetle predators and parasitoids to infested areas.

The diversity of volatile compounds emitted by bark beetle-associated fungi holds great potential for the development of new semiochemical-based control measures for these insects. Further research on the identification of fungal volatiles and their effect on the behavior of bark beetles and their natural enemies will provide knowledge that could be exploited for protection of conifer forests. At present, however, applications of semiochemicals for bark beetle management in natural forests are hampered by the scale at which they would have to be deployed. In small conifer plantations, on the other hand, these techniques may be effective, and logistically and economically possible. Small plantations even could exploit fungal cell cultures as baits in traps for attracting bark beetles. A recent study showed that a large range of insects encompassing seven different orders were significantly attracted to a cell culture of the ubiquitous fungus, Aureobasidium pullulans (De Bary) G. Arnaud ex Ciferri, Ribaldi \& Corte, in traps (Davis and Landolt 2013). One might question whether the amounts of volatiles emitted from fungal cell cultures are sufficient for attracting bark beetles, but beetles are able to perceive some volatile compounds in nanogram or even picogram doses (Andersson et al. 2009). Another factor to consider is that emission of volatiles from fungal cultures may be variable. In our experiments, we found that fungal volatile emissions differed with nutrient availability, and that emissions decreased once the growth medium was depleted. Furthermore, the ecological consequences of using living fungal cultures in traps are still unknown. There is a risk of introducing pathogens to naïve forests, and local laws likely will not permit the usage of potentially pathogenic fungi in forest ecosystems.

Employing fungal volatiles may circumvent these problems because pure substances with attractive or repellent activity can be deployed in pheromone dispensers in combination with known commercial products for bark beetle control. As an example, lethal laurel wilt disease in red bay and avocado trees is caused by the fungus Raffaella lauricola, which is associated with an invasive ambrosia beetle, Xyleborus glabratus (Fraedrich et al. 2008). The major volatile metabolites of $R$. lauricola when cultivated on potato dextrose agar 
are isoamyl alcohol, isoamyl acetate, ethanol, ethyl acetate, and isobutyl alcohol (Kuhns et al. 2014). In field assays, the synthetic blend of these $R$. lauricola volatiles, together with volatiles that mimic the host tree, synergistically increased the attraction of beetles to traps compared to host volatiles alone, underlining the value of using microbial volatiles together with already available attractive mixtures (Hulcr et al. 2011; Kuhns et al. 2014). Because ambrosia beetles are phylogenetically closely related to bark beetles, similar strategies might also prove effective in controlling bark beetles. However, there is a need to first evaluate the efficiency with which bark beetles can be trapped in the field using synthetic blends of fungal volatiles together with other known attractants or repellents.

Biomarkers Identification of ophiostomatoid fungi through chemotyping of their volatiles could be a promising application of the volatile secondary metabolites produced by these microorganisms. Volatiles have previously proven helpful in the differentiation and identification of fungi to the species level (Larsen and Frisvad 1995; Polizzi et al. 2012). Furthermore, researchers also have predicted the ecological function of fungal species based on their volatile emission patterns (Muller et al. 2013). This approach could be employed during attack by a bark beetle like I. typographus, for example, to gain a precise overview of the abundance and succession of the different fungal associates present given the distinctive volatile profiles they showed in our survey. In light of the different properties of the various fungal associates, such information would help predict the speed and virulence of bark beetle outbreaks when obtained on a landscape scale. It also could help provide evidence for the degree of association between fungus and beetle, which ranges from obligate to facultative (Table 1). Because volatiles can be measured in the field in real-time throughout the season by using technology such as proton-transfer reaction mass spectrometry, monitoring of profiles of volatiles represents an attractive noninvasive alternative to culture-based methods for determining the occurrence of fungal species. Although all fungal species included in the current study are culturable, the presence of one species may inhibit the growth of others in culture, which could lead to a bias in estimating species abundance that would be avoided by volatile identification in the field. In theory, the spectrum of volatiles emitted by a fungal taxon could be altered by growth with another fungus, but in previous studies co-cultivation did not affect the qualitative emission profiles (Weikl et al. 2016).

The systematics of ophiostomatoid fungi is complex, and collections often are misidentified due to morphological similarities within this group. Because differences in the profiles of volatiles produced by different phenotypes reflect changes on the genetic level, chemosystematics based on volatile organic compounds could be useful to taxonomists and ecologists for better identification and classification of fungi in this group. Studies have shown that cryptic species within a species complex differ significantly in their volatile profiles (Ludwiczuk et al. 2013; Wawrzyniak et al. 2014), and so by using such methods it should be possible to differentiate among the cryptic species previously described in the G. clavigera complex (Alamouti et al. 2011).

Monitoring of volatiles could be especially useful in preventing introductions of bark beetles and their associated fungi into new areas. Routine analysis of volatiles emitted from wood shipments originating from foreign sources might be an effective screening method to identify low level infestations of new potentially invasive species. Monitoring fungal volatiles in forest ecosystems also might provide a method for early detection of new bark beetle invasions that could lead to timely eradication of new pest species before they become established.

\section{Conclusions}

Research on the chemical ecology of bark beetles conducted over many years has revealed much about how beetles aggregate and choose host trees. However, most workers have focused on the chemical compounds originating from the beetles and their host trees, with little attention given to chemical signals originating from the beetle's fungal associates. Given the pivotal role of fungi in the success of bark beetle infestation of host trees, a better knowledge of the chemical interactions between beetle and fungus should substantially increase our understanding of bark beetle life history. This information in turn will be of great value in refining existing techniques for management of bark beetle pest species and developing new approaches. Deployment of fungal volatiles as attractants or deterrents, alone or in combination with other types of semiochemicals, could significantly improve our ability to control these destructive forest pests.

Acknowledgments We thank the Max Planck Society for support and Jocelyn Millar and two anonymous reviewers for their very helpful comments on an earlier draft. Open access funding provided by Max Planck Society.

Open Access This article is distributed under the terms of the Creative Commons Attribution 4.0 International License (http:// creativecommons.org/licenses/by/4.0/), which permits unrestricted use, distribution, and reproduction in any medium, provided you give appropriate credit to the original author(s) and the source, provide a link to the Creative Commons license, and indicate if changes were made.

\section{References}

Adams AS, Six DL (2008) Detection of host habitat by parasitoids using cues associated with mycangial fungi of the mountain pine beetle, Dendroctonus ponderosae. Can Entomol 140:124-127 
Adams AS, Aylward FO, Adams SM, Erbilgin N, Aukema BH, Currie CR, Suen G, Raffa KF (2013) Mountain pine beetles colonizing historical and naive host trees are associated with a bacterial community highly enriched in genes contributing to terpene metabolism. Appl Environ Microbiol 79:3468-3475

Addison AL, Powell JA, Six DL, Moore M, Bentz BJ (2013) The role of temperature variability in stabilizing the mountain pine beetle-fungus mutualism. J Theor Biol 335:40-50

Akbulut S, Stamps WT (2012) Insect vectors of the pinewood nematode: a review of the biology and ecology of Monochamus species. For Pathol 42:89-99

Alamouti SM, Wang V, Diguistini S, Six DL, Bohlmann J, Hamelin RC, Feau N, Breuil C (2011) Gene genealogies reveal cryptic species and host preferences for the pine fungal pathogen Grosmannia clavigera. Mol Ecol 20:2581-2602

Andersson MN, Larsson MC, Schlyter F (2009) Specificity and redundancy in the olfactory system of the bark beetle Ips typographus: single-cell responses to ecologically relevant odors. J Insect Physiol 55:556-567

Aukema BH, Werner RA, Haberkern KE, Illman BL, Clayton MK, Raffa KF (2005) Quantifying sources of variation in the frequency of fungi associated with spruce beetles: implications for hypothesis testing and sampling methodology in bark beetle-symbiont relationships. For Ecol Manag 217:187-202

Ayres MP, Wilkens RT, Ruel JJ, Lombardero MJ, Vallery E (2000) Nitrogen budgets of phloem-feeding bark beetles with and without symbiotic fungi. Ecology 81:2198-2210

Bakke A (1991) Using pheromones in the management of bark beetle outbreaks. General technical report NE - U.S. Department of agriculture, forest service, Northeastern forest experiment station 153: $371-337$

Barras S (1970) Antagonism between Dendroctonus frontalis and the fungus Ceratocystis minor. Ann Entomol Soc Am 63:1187-1190

Barras S (1973) Reduction of progeny and development in the southern pine beetle following removal of symbiotic fungi. Can Entomol 105: 1295-1299

Barras S, Perry T (1972) Fungal symbionts in the prothoracic mycangium of Dendroctonus frontalis (Coleopt.: Scolytidae. J Appl Entomol 71: 95-104

Bartlet R, Wicklow D (1999) Volatiles from Fusarium verticillioides (Sacc.) Nirenb. and their attractiveness to nitidulid beetles. J Agric Food Chem 47:2447-2454

Bentz BJ, Six DL (2006) Ergosterol content of fungi associated with Dendroctonus ponderosae and Dendroctonus rufipennis (Coleoptera: Curculionidae, Scolytinae). Ann Entomol Soc Am 99:189-194

Bentz BJ, Regniere J, Fettig CJ, Hansen EM, Hayes JL, Hicke JA, Kelsey RG, Negron JF, Seybold SJ (2010) Climate change and bark beetles of the western United States and Canada: direct and indirect effects. Bioscience 60:602-613

Bleiker KP, Six DL (2007) Dietary benefits of fungal associates to an eruptive herbivore: Potential implications of multiple associates on host population dynamics. Environ Entomol 36:1384-1396

Bleiker KP, Potter SE, Lauzon CR, Six DL (2009) Transport of fungal symbionts by mountain pine beetles. Can Entomol 141:503-514

Blomquist GJ, Figueroa-Teran R, Aw M, Song M, Gorzalski A, Abbott NL, Chang E, Tittiger C (2010) Pheromone production in bark beetles. Insect Biochem Mol Biol 40:699-712

Boone CK, Six DL, Zheng YB, Raffa KF (2008) Parasitoids and dipteran predators exploit volatiles from microbial symbionts to locate bark beetles. Environ Entomol 37:150-161

Borden JH (1989) Semiochemicals and bark beetle populations: exploitation of natural phenomena by pest management strategists. Ecography 12:501-510

Borden JH, Wilson IM, Gries R, Chong LJ, Pierce HD Jr, Gries G (1998) Volatiles from the bark of trembling aspen, Populus tremuloides
Michx.(Salicaceae) disrupt secondary attraction by the mountain pine beetle, Dendroctonus ponderosae Hopkins (Coleoptera: Scolytidae. Chemoecology 8:69-75

Borden JH, Pureswaran DS, Poirier LM (2004) Evaluation of two repellent semiochemicals for disruption of attack by the mountain pine beetle, Dendroctonus ponderosae Hopkins (Coleoptera: Scolytidae). J Entomol Soc B C 101:117-124

Borden JH, Birmingham AL, Burleigh JS (2006) Evaluation of the pushpull tactic against the mountain pine beetle using verbenone and non-host volatiles in combination with pheromone-baited trees. For Chron 82:579-590

Boulogne I, Petit P, Ozier-Lafontaine H, Desfontaines L, LorangerMerciris G (2012) Insecticidal and antifungal chemicals produced by plants: a review. Environ Chem Lett 10:325-347

Bracewell RR, Six DL (2014) Broadscale specificity in a bark beetlefungal symbiosis: A spatio-temporal analysis of the mycangial fungi of the western pine beetle. Microb Ecol 68:859-870

Bracewell RR, Six DL (2015) Experimental evidence of bark beetle adaptation to a fungal symbiont. Ecol Evol 5:5109-5119

Brand JM, Bracke J, Britton L, Markovetz A, S B (1976) Bark beetle pheromones: Production of verbenone by a mycangial fungus of Dendroctonus frontalis. J Chem Ecol 3:657-666

Brand JM, Schulz J, Barras SJ, Edson LJ, Paine TL, Hedden RL (1977) Bark beetle pheromones: enhancement of Dendroctonus frontalis (Coleoptera: Scolytidae) aggregation pheromone by yeast metabolites in laboratory bioassays. J Chem Ecol 3:657-666

Bridges J, Perry T (1985) Effects of mycangial fungi on gallery construction and distribution of bluestain in southern pine beetle-infested pine bolts. J Entomol Sci 20:271-275

Byres J, Zhang Q, Birgersson G (2004) Avoidance of nonhost plants by a bark beetle, Pityogenes bidentatus, in a forest of odors. Naturwissenschaften 91:215-219

Cardoza YJ, Moser JC, Klepzig KD, Raffa KF (2008) Multipartite symbioses among fungi, mites, nematodes, and the spruce beetle, Dendroctonus rufipennis. Environ Entomol 37:956-963

Christianens J, Franco L, Cools T, De Meester L, Michiels J, Wenseleers T, Hassan B, Yaksie E, Verstrepen K (2014) The fungal aroma gene ATF1 promotes dispersal of yeast cells through insect vectors. Cell Rep 9:425-432

Christiansen E, Bakke A (1988) The spruce bark beetle of Eurasia. In: Berryman A, (ed) Dynamics of forest insect populations, Springer, pp 479-503

Clayton RB (1964) The utilization of sterols by insects. J Lipid Res 5:319

Combet E, Henderson J, Eastwood D, Burton K (2006) Eight-carbon volatiles in mushrooms and fungi: properties, analysis, and biosynthesis. Mycoscience 47:317-326

Cook SM, Khan ZR, Pickett JA (2006) The use of push-pull strategies in integrated pest management. Annu Rev Entomol 52

Cook SP, Shirley BM, Zambino PJ (2010) Nitrogen concentration in mountain pine beetle larvae reflects nitrogen status of the tree host and two fungal associates. Environ Entomol 39:821-826

Coppedge BR, Stephen FM, Felton GW (1995) Variation in female southern pine beetle size and lipid content in relation to fungal associates. Can Entomol 127:145-154

Cudmore TJ, Bjorklund N, Carrol AL, Staffan-Lindgren B (2010) Climate change and range expansion of an aggressive bark beetle: evidence of higher beetle reproduction in naïve host tree populations. J Appl Ecol 47:1036-1043

Davis TS, Landolt PJ (2013) A survey of insect assemblages responding to volatiles from a ubiquitous fungus in an agricultural landscape. $\mathrm{J}$ Chem Ecol 39:860-868

De Beer ZW, Duong TA, Barnes I, Wingfield BD, Wingfield MJ (2014) Redefining Ceratocystis and allied genera. Stud Mycol 79:187-219 
Dickens JC, Billings RF, Payne TL (1992) Green leaf volatiles interrupt aggregation pheromone response in bark beetles infesting southern pines. Experientia 48:523-524

Diguistini S, Wang Y, Liao NY, Taylor G, Tanguay P, Feau N, Henrissat B, Chan SK, Hesse-Orce U, Alamouti SM and others (2011) Genome and transcriptome analyses of the mountain pine beetlefungal symbiont Grosmannia clavigera, a lodgepole pine pathogen. Proc Natl Acad Sci U S A 108:2504-2509

El-Sayed AM, Suckling DM, Byers JA, Jang EB, Wearing CH (2009) Potential of "lure and kill" in long-term pest management and eradication of invasive species. J Econ Entomol 102:815-835

Erbilgin N, Gillette NE, Mori SR, Stein JD, Owen DR, Wood DL (2007) Acetophenone as an anti-attractant for the western pine beetle, Dendroctonus brevicomis LeConte (Coleoptera: Scolytidae. J Chem Ecol 33:817-823

Erbilgin N, Gillette NE, Owen DR, Mori SR, Nelson AS, Uzoh F, Wood DL (2008) Acetophenone superior to verbenone for reducing attraction of western pine beetle Dendroctonus brevicomis to its aggregation pheromone. Agric For Entomol 10:433-441

Erbilgin N, Ma C, Whitehouse C, Shan B, Najar A, Evenden M (2014) Chemical similarity between historical and novel host plants promotes range and host expansion of the mountain pine beetle in a naive host ecosystem. New Phytol 201:940-950

Fraedrich SW, Harrington TC, Rabaglia RJ, Ulyshen MD, Mayfield AE, Hanula JL, Eickwort JM, Miller DR (2008) A fungal symbiont of the redbay ambrosia beetle causes a lethal wilt in redbay and other Lauraceae in the southeastern United States. Plant Dis 92:215-224

Furniss M, Solhheim H, Christiansen E (1990) Transmission of blue-stain fungi by Ips typographus (Coleoptera: Scolytidae) in Norway spruce. Ann Entomol Soc Am 83:712-716

Furniss M, Harvey A, Solhheim H (1995) Transmission of Ophiostoma ips (Ophiostomatales: Ophiostomataceae) by Ips pini (Coleoptera: Scolytidae) to ponderosa pine in Idaho. Ann Entomol Soc Am 88: 653-660

Gillette NE, Stein JD, Owen DR, Webster JN, Fiddler GO, Mori SR, Wood DL (2006) Verbenone-releasing flakes protect individual Pinus contorta trees from attack by Dendroctonus ponderosae and Dendroctonus valens (Coleoptera: Curculionidae, Scolytinae. Agric For Entomol 8:243-251

Gillette NE, Mehmel CJ, Mori SR, Webster JN, Wood DL, Erbilgin N, Owen DR (2012) The push-pull tactic for mitigation of mountain pine beetle (Coleoptera: Curculionidae) damage in lodgepole and whitebark pines. Environ Entomol 41:1575-1586

Giordano L, Garbelotto M, Nicolotti G, Gonthier P (2013) Characterization of fungal communities associated with the bark beetle Ips typographus varies depending on detection method, location, and beetle population levels. Mycol Prog 12:127-140

Goldhammer DS, Stephen FM, Paine TD (1990) The effect of the fungi Ceratocystis minor (Hedgcock) hunt, Ceratocystis minor (Hedgcock) hunt var. barrasii Taylor, and SJB 122 on reproduction of the southern pine beetle, Dendroctonus frontalis Zimmermann (Coleoptera: Scolytidae. Can Entomol 122:407-418

Grosman DM, Clarke SR, Upton WW (2009) Efficacy of two systemic insecticides injected into loblolly pine for protection against southern pine bark beetles (Coleoptera: Curculionidae. J Econ Entomol 102:1062-1069

Hammerbacher A, Schmidt A, Wadke N, Wright L, Schneider B, Brand WA, Fenning TM, Gershenzon J, Paetz C (2013) A common fungal associate of the spruce bark beetle metabolizes the stilbene defenses of Norway spruce. Plant Physiol 162:1324-1336

Happ GM, Happ CM, Barras SJ (1971) Fine structure of the prothoracic mycangium, a chamber for the culture of symbiotic fungi, in the southern pine beetle, Dendroctonus frontalis. Tissue Cell 3:295-308

Harrington, TC (2005) Ecology and evolution of mycophagous bark beetles and their fungal partners. In: Vega F, Blackwell M, (eds)
Ecological and evolutionary advances in insect-fungal associations, Oxford University Press, pp 257-291

Hart SJ, Veblen TT, Eisenhart KS, Jarvis D, Kulakowski D (2014) Drought induces spruce beetle (Dendroctonus rufipennis) outbreaks across northwestern Colorado. Ecology 95:930-939

Hazelwood LA, Daran JM, Van Maris AJ, Pronk JT, Dickinson JR (2008) The Ehrlich pathway for fusel alcohol production: a century of research on Saccharomyces cerevisiae metabolism. Appl Environ Microbiol 74:2259-2266

Hemingway RW, Mcgraw GW, Barras SJ (1977) Polyphenols in Ceratocystis minor infected Pinus taeda: fungal metabolites, phloem and xylem phenols. J Agric Food Chem 25:717-722

Hodges JD, Barras SJ, Mauldin JK (1968) Amino acids in inner bark of loblolly pine, as affected by the southern pine beetle and associated microorganisms. Can J Bot 46:1467-1472

Hofstetter RW, Cronin JT, Klepzig KD, Moser JC, Ayres MP (2006a) Antagonisms, mutualisms and commensalisms affect outbreak dynamics of the southern pine beetle. Oecologia 147:679-691

Hofstetter RW, Klepzig KD, Moser JC, Ayres MP (2006b) Seasonal dynamics of mites and fungi and their interaction with Southern pine beetle. Environ Entomol 35:22-30

Hokkanen HM (1991) Trap cropping in pest management. Annu Rev Entomol 36:119-138

Hubbell SP, Wiemer DF, Adejare A (1983) An antifungal terpenoid defends a neotropical tree (Hymenaea) against attack by fungusgrowing ants (Atta. Oecologia 60:321-327

Huber DP, Gries R, Borden JH, Pierce Jr. HD (2000) A survey of antennal responses by five species of coniferophagous bark beetles (Coleoptera: Scolytidae) to bark volatiles of six species of angiosperm trees. Chemoecology 10:103-113

Huber DP, Borden JH, Stastny M (2001) Response of the pine engraver, Ips pini (Say)(Coleoptera: Scolytidae), to conophthorin and other angiosperm bark volatiles in the avoidance of non-hosts. Agric For Entomol 3:225-232

Hughes PR (1973) Dendroctonus: Production of pheromones and related compounds in response to host monoterpenes. Z Angew Entomol 73:294-312

Hulcr J, Mann R, Stelinski LL (2011) The scent of a partner: ambrosia beetles are attracted to volatiles from their fungal symbionts. J Chem Ecol 37:1374-1377

Hunt RS, Poinar GO (1971) Culture of a Parasitorhabditis sp. (Rhabditida: Protorhabditinae) on a fungus. Nematologica 17:321-322

Jankowiak R, Kacprzyk M, Mlynarczyk M (2009) Diversity of ophiostomatoid fungi associated with bark beetles (Coleoptera: Scolytidae) colonizing branches of Norway spruce (Picea abies) in southern Poland. Biologia 64:1170-1177

Janson EM, Stireman JO 3rd, Singer MS, Abbot P (2008) Phytophagous insect-microbe mutualisms and adaptive evolutionary diversification. Evolution 62:997-1012

Kausrud K, Okland B, Skarpaas O, Gregoire JC, Erbilgin N, Stenseth NC (2012) Population dynamics in changing environments: the case of an eruptive forest pest species. Biol Rev Camb Philos Soc 87:34-51

Keller NP, Turner G, Bennett JW (2005) Fungal secondary metabolism from biochemistry to genomics. Nat Rev Microbiol 3:937-947

Kim J, Seo SM, Park IK (2011) Nematicidal activity of plant essential oils and components from Gaultheria fragrantissima and Zanthoxylum alatum against the pine wood nematode, Bursaphelenchus xylophilus. Nematology 13:87-93

Kirisits T (2004) Fungal associates of European bark beetles with special emphasis on the ophiostomatoid fungi. Lieutier F, Day K, Battisti A, Gregoire J-C, Evans H, eds.: Springer, Dordrecht. 181-236

Kirisits T (2010) Fungi isolated from Picea abies infested by the bark beetle Ips typographus in the Białowieża forest in North-Eastern Poland. For Pathol 40:100-110 
Kopper BJ, Klepzig KD, Raffa KF (2004) Components of antagonism and mutualism in Ips pini-fungal interactions: relationship to a life history of colonizing highly stressed and dead trees. Environ Entomol 33:28-34

Kramer R, Abraham W-R (2012) Volatile sesquiterpenes from fungi: what are they good for? Phytochem Rev 11:15-37

Krokene P, Solhheim H (1996) Fungal associates of five bark beetle species colonizing Norway spruce. Can J For Res 26:2115-2122

Krokene P, Solhheim H (1998) Pathogenicity of four blue-stain fungi associated with aggressive and nonaggressive bark beetles. Phytopathology 88:39-44

Krokene P, Solhheim H (2002) Assessing the virulence of four bark beetle-associated bluestain fungi using Norway spruce seedlings. Plant Pathol 47:537-540

Kuhns EH, Tribuiani Y, Martini X, Meyer WL, Pena J, Hulcr J, Stelinski LL (2014) Volatiles from the symbiotic fungus Raffaelea lauricolaare synergistic with Manuka lures for increased capture of the Redbay ambrosia beetle Xyleborus glabratus. Agric For Entomol 16:87-94

Kurz WA, Dymond CC, Stinson G, Rampley GJ, Neilson ET, Carrol AL, Ebata T, Safrantik L (2008) Mountain pine beetle and forest carbon feedback to climate change. Nature 452:987-990

Lapadatescu C, Ginies C, Le Quere JL, Bonnarme P (2000) Novel scheme for biosynthesis of aryl metabolites from L-phenylalanine in the fungus Bjerkandera adusta. Appl Environ Microbiol 66: $1517-1522$

Larsen TO, Frisvad JC (1995) Chemosystematics of Penicillium based on profiles of volatile metabolites. Mycol Res 99:1167-1174

Leufven A, Bergstrom G, Falsen E (1984) Interconversion of verbenols and verbenone by identified yeasts isolated from the spruce bark beetle Ips typographus. J Chem Ecol 10:1349-1361

Linnakoski R, Mahilainen S, Harrington A, Vanhanen H, Eriksson M, Mehtatalo L, Pappinen A, Wingfield MJ (2016) Seasonal succession of fungi associated with Ips typographus beetles and their phoretic mites in an outbreak region of Finland. PLoS One 11: $\mathrm{e} 0155622$

Ludwiczuk A, Odrzykoski IJ, Asakawa Y (2013) Identification of cryptic species within liverwort Conocephalum conicum based on the volatile components. Phytochemistry 95:234-241

Maehara N, Futai K (1997) Effect of fungal interactions on the numbers of the pinewood nematode, Bursaphelenchus xylophilus (Nematoda: Aphelenchoididae), carried by the Japanese pine sawyer, Monochamus alternatus (Coleoptera: Cerambycidae. Fundam Appl Nematol 20:611-617

Maroja LS, Bogdanowics SM, Wallin KF, Raffa KF, Harrison RG (2007) Phylogeography of spruce beetles (Dendroctonus rufipennis Kirby) (Curculionidae: Scolytinae) in North America. Mol Ecol 16:2560 2573

Mayo P, Silk P, Cusson M, Beliveau C (2013) Steps in the biosynthesis of fuscumol in the longhorn beetles Tetropium fuscum (F.) and Tetropium cinnamopterum Kirby. J Chem Ecol 39:377-389

Mburu D, Maniania N, Hassanali A (2013) Comparison of volatile blends and nucleotide sequences of two Beauveria bassiana isolates of different virulence and repellency towards the termite Macrotermes michealseni. J Chem Ecol 39:101-108

Mondy N, Corio-Costet MF (2000) The response of the grape berry moth (Lobesia botrana) to a dietary phytopathogenic fungus (Botrytis cinerea): the significance of fungus sterols. J Insect Physiol 46: $1557-1564$

Moore ML, Six DL (2015) Effects of temperature on growth, sporulation, and competition of mountain pine beetle fungal symbionts. Microb Ecol 70:336-347

Morimoto M, Fujii Y, Komai K (1999a) Antifeedants in Cyperaceae: coumaran and quinones from Cyperus spp. Phytochemistry 51: 605-608
Morimoto M, Urakawa M, Fujitaka T, Komai K (1999b) Structure-activity relationships for the insect antifeedant activity of benzofuran derivatives. Biosci Biotechnol Biochem 63:840-846

Muller A, Faubert P, Hagen M, Zu Castell W, Polle A, Schnitzler JP, Rosenkranz M (2013) Volatile profiles of fungi - chemotyping of species and ecological functions. Fungal Genet Biol 54:25-33

O'Halloran DM, Burnell AM (2003) An investigation of chemotaxis in the insect parasitic nematode Heterorhabditis bacteriophora. Parasitology 127:375-385

Persson Y, Vasaitis R, Langstrom B, Ohrn P, Ihrmark K, Stenlid J (2009) Fungi vectored by the bark beetle Ips typographus following hibernation under the bark of standing trees and in the forest litter. Microb Ecol 58:651-659

Pettersson EM (2001) Volatile attractants for three pteromalid parasitoids attacking concealed spruce bark beetles. Chemoecology 11:89-95

Pettersson EM, Boland W (2003) Potential parasitoid attractants, volatile composition throughout a bark beetle attack. Chemoecology 13:2737

Pires EJ, Teixeira JA, Branyik T, Vicente AA (2014) Yeast: the soul of beer's aroma-a review of flavour-active esters and higher alcohols produced by the brewing yeast. Appl Microbiol Biotechnol 98: 1937-1949

Poland TM, Borden JH, Stock AJ, Chong LJ (1998) Green leaf volatiles disrupt responses by the spruce beetle, Dendroctonus rufipennis, and the western pine beetle, Dendroctonus brevicomis (Coleoptera: Scolytidae) to attractant-baited traps. J Entomol Soc B C 95:17-24

Polizzi V, Adams A, Malysheva SV, De Saeger S, Van Peteghem C, Moretti A, Picco AM, De Kimpe N (2012) Identification of volatile markers for indoor fungal growth and chemotaxonomic classification of Aspergillus species. Fungal Biol 116:941-953

Pureswaran DS, Borden JH (2004) New repellent semiochemicals for three species of Dendroctonus (Coleoptera: Scolytidae. Chemoecology 14:67-75

Pureswaran DS, Gries R, Borden JH, Pierce HD Jr (2000) Dynamics of pheromone production and communication in the mountain pine beetle, Dendroctonus ponderosae Hopkins, and the pine engraver, Ips pini (Say)(Coleoptera: Scolytidae. Chemoecology 10:153-168

Raffa KF, Aukema BH, Bentz BJ, Carroll AL, Hicke JA, Turner MG, Romme WH (2008) Cross-scale drivers of natural disturbances prone to anthropogenic amplification: the dynamics of bark beetle eruptions. Bioscience 58:501-517

Rajashekar Y, Raghavendra A, Bakthavatsalam N (2014) Acetylcholinesterase inhibition by biofumigant (Coumaran) from leaves of Lantana camara in stored grain and household insect pests. Biomed Res Int 2014:187019

Rasmann S, Köllner TG, Degenhardt J, Hiltpold I, Toepfer S, Kuhlmann U, Gershenzon J, Turlings TC (2005) Recruitment of entomopathogenic nematodes by insect-damaged maize roots. Nature 434:732737

Repe A, Kirisits T, Piscur B, De Groot M, Klump B, Jurc M (2013) Ophiostomatoid fungi associated with three spruce-infesting bark beetles in Slovenia. Annals. For Sci 70:717-727

Sauvard D (2004) General biology of bark beetles. In: Lieutier F, Day KR, Battisti A, Grégoire J-C, Evans HF (eds) Bark and wood boring insects in living trees in Europe, a synthesis. Springer Netherlands, Dordrecht, pp. 63-88

Sawahata T, Shimano S, Suzuki M (2008) Tricholoma matsutake, 1octen-3-ol and methyl cinnamate repel mycophagous Proisotoma minuta (Collembola: Insecta. Mycorrhiza 18:111-114

Schiebe C, Blaženec M, Jakuš R, Unelius CR, Schlyter F (2011) Semiochemical diversity diverts bark beetle attacks from Norway spruce edges. J Appl Entomol 135:726-737

Schlyter F, Birgersson G, Byres JA, Lofqvist J, Bergstrom G (1987) Field response of spruce bark beetle, Ips typographus, to aggregation pheromone candidates. J Chem Ecol 13:701-716 
Shea P, Neustein M (1995) Protection of a rare stand of Torrey pine from Ips paraconfusus. Application of semiochemicals for management of bark beetle infestations - Proceedings of an Informal Conference USDA, Forest Service. General Technical Report INT: GTR-318, pp 123-456

Shea PJ, Mcgregor MD, Daterman GE (1992) Aerial application of verbenone reduces attack of lodgepole pine by mountain pine beetle. Can J For Res 22:436-441

Silverstein RM, Rodin JO, Wood DL (1966) Sex attractants in frass produced by male Ips confusus in ponderosa pine. Science 154: 509-510

Silverstein RM, Brownlee RG, Bellas TE, Wood DL, Browne LE (1968) Brevicomin: principal sex attractant in the frass of the female western pine beetle. Science 159:889-891

Six DL (2003) A comparison of mycangial and phoretic fungi of individual mountain pine beetles. Can J For Res 33:1331-1334

Six DL (2012) Ecological and evolutionary determinants of bark beetlefungus symbioses. Insects 3:339-366

Six DL (2013) The bark beetle holobiont: Why microbes matter. J Chem Ecol 39:989-1002

Six DL, Bentz BJ (2003) Fungi associated with the North American spruce beetle, Dendroctonus rufipennis. Can J For Res 33:18151820

Six DL, Bentz BJ (2007) Temperature determines symbiont abundance in a multipartite bark beetle-fungus ectosymbiosis. Microb Ecol 54: $112-118$

Six DL, Paine TD (1998) Effects of mycangial fungi and host tree species on progeny survival and emergence of Dendroctonus ponderosae (Coleoptera: Scolytidae). Environ Entomol 27:1393-1401

Six DL, Wingfield MJ (2011) The role of phytopathogenicity in bark beetle-fungus symbioses: A challenge to the classic paradigm. Annu Rev Entomol 56:255-272

Solheim H (1991a) The early stages of fungal invasion in Norway spruce infested by the bark beetle Ips typographus. Can J Bot 70:1-5

Solheim H (1991b) Oxygen deficiency and spruce resin inhibition of growth of blue stain fungi associated with Ips typographus. Mycol Res 95:1387-1392

Solheim H (1992) Fungal succession in sapwood of Norway spruce infested by the bark beetle Ips typographus. Eur J For Pathol 22: $136-148$

Solheim H, Krokene P (1998) Growth and virulence of mountain pine beetle associated blue-stain fungi, Ophiostoma clavigerum and Ophiostoma montium. Can J Bot 76:561-566

Spatafora JW, Blackwell M (1994) The polyphyletic origins of ophiostomatoid fungi. Mycol Res 98:1-9

Suh D, Hyun M, Kim J, Son S, Kim S (2013) Ophiostoma ips from pinewood nematode vector, japanese pine sawyer beetle (Monochamus alternatus), in Korea. Mycobiology 41:59-62

Sullivan BT (2005) Electrophysiological and behavioral responses of Dendroctonus frontalis (Coleoptera: Curculionidae) to volatiles isolated from conspecifics. J Econ Entomol 98:2067-2078

Sullivan BT, Berisford CW (2004) Semiochemicals from fungal associates of bark beetles may mediate host location behavior of parasitoids. J Chem Ecol 30:703-717

Sullivan BT, Dalusky MJ, Wakarchuk D, Berisford CW (2007) Field evaluations of potential aggregation inhibitors for the southern pine beetle, Dendroctonus frontalis (Coleoptera: Curculionidae. J Entomol Sci 42:139-149

Therrien J, Mason CJ, Cale JA, Adams A, Aukema BH, Currie CR, Raffa KF, Erbilgin N (2015) Bacteria influence mountain pine beetle brood development through interactions with symbiotic and antagonistic fungi: implications for climate-driven host range expansion. Oecologia 179:467-485

Ungerer MJ, Ayres MP, Lombardero MJ (1999) Climate and the northern distribution limits of Dendroctonus frontalis Zimmermann (Coleoptera: Scolytidae. J Biogeogr 26:1133-1145
Viiri H, Lieutier F (2004) Ophiostomatoid fungi associated with the spruce bark beetle, Ips typographus, in three areas in France. Annals For Sci 61:215-219

Vite JP, Bakke A, Renwick JA (1972) Pheromones in Ips (ColeopteraScolytidae) - occurrence and production. Can Entomol 104:19671975

Wadke N, Kandasamy D, Vogel H, Lah L, Wingfield BD, Paetz C, Wright LP, Gershenzon J, Hammerbacher A (2016) The bark-beetle-associated fungus, Endoconidiophora polonica, utilizes the phenolic defense compounds of its host as a carbon source. Plant Physiol 171:914-931

Wang Y, Lim L, DG S, Robertson G, Bohlmann J, Breuil C (2013) A specialized $\mathrm{ABC}$ efflux transporter GcABC-G1 confers monoterpene resistance to Grosmannia clavigera, a bark beetle-associated fungal pathogen of pine trees. New Phytol 197:886-898

Wang Y, Lim L, Madilao L, Lah L, Bohlmann J, Breuil C (2014) Gene discovery for enzymes involved in limonene modification or utilization by the mountain pine beetle-associated pathogen Grosmannia clavigera. Appl Environ Microbiol 80:4566-4576

Wawrzyniak R, Wasiak W, Bączkiewicz A, Buczkowska K (2014) Volatile compounds in cryptic species of the Aneura pinguis complex and Aneura maxima (Marchantiophyta, Metzgeriidae. Phytochemistry 105:115-122

Weikl F, Ghirardo A, Schnitzler JP, Pritsch K (2016) Sesquiterpene emissions from Alternaria alternata and Fusarium oxysporum: effects of age, nutrient availability, and co-cultivation. Sci Rep 6

Wermelinger B (2004) Ecology and management of the spruce bark beetle Ips typographus - a review of recent research. For Ecol Manag 202:67-82

Whitney H, Farris S (1970) Maxillary mycangium in the mountain pine beetle. Science 167:54-55

Widhalm JR, Dudareva N (2015) A familiar ring to it: biosynthesis of plant benzoic acids. Mol Plant 8:83-97

Wood DL (1982a) The role of pheromones, kairomones, and allomones in the host selection and colonization behavior of bark beetles. Annu Rev Entomol 27:411-446

Wood SL (1982b) The bark and ambrosia beetles of North and Central America (Coleoptera: Scolytidae), a taxonomic monograph. Great Basin Nat Memoirs 6:1-1359

Wood DL, Stark RW, Silverstein RM, Rodin JO (1967) Unique synergistic effects produced by the principal sex attractant compounds of Ips confusus (LeConte) (Coleoptera: Scolytidae. Nature 215

Yamaoka Y, Wingfield MJ, Takahashi I, Solheim H (1997) Ophiostomatoid fungi associated with the spruce bark beetle Ips typographus $f$. japonicus in Japan. Mycol Res 101:1215-1227

Yearian WC, Gouger RJ, Wilkinson RC (1972) Effects of the bluestain fungus, Ceratocystis ips, on development of Ips bark beetles in pine bolts. Ann Entomol Soc Am 65:481-487

Zhang Q-H, Schlyter F, Anderson P (1999) Green leaf volatiles interrupt pheromone response of spruce bark beetle, Ips typographus. J Chem Ecol 25:2847-2861

Zhang Q-H, Schlyter F, Birgersson G (2000) Bark volatiles from nonhost angiosperm trees of spruce bark beetle, Ips typographus (L.)(Coleoptera: Scolytidae): chemical and electrophysiological analysis. Chemoecology 10:69-80

Zhang QH, Schlyter F, Chen GG, Wang Y (2007) Electrophysiological and behavioral responses of Ips subelongatus to semiochemicals from its hosts, non-hosts, and conspecifics in China. J Chem Ecol 33:391-404

Zhang L, Chen H, Ma C, Tian Z (2010) Electrophysiological responses of Dendroctonus armandi (Coleoptera: Curculionidae: Scolytinae) to volatiles of Chinese white pine as well as to pure enantiomers and racemates of some monoterpenes. Chemoecology 20:265-275

Zhao T, Krokene P, Hu J, Christiansen E, Bjorklund N, Langstrom B, Solheim H, Borg-Karlson AK (2011) Induced terpene accumulation 
in Norway spruce inhibits bark beetle colonization in a dose-dependent manner. PLoS One 6

Zhao T, Axelsson K, Borg-Karlson AK (2015) Fungal symbionts of the spruce bark beetle synthesize the beetle aggregation pheromone 2methyl-3-buten-2-ol. J Chem Ecol 41:848-852

Zhou X, De Beer ZW, Wingfield BD, Wingfield MJ (2002) Infection sequence and pathogenicity of Ophiostoma ips, Leptographium serpens and L. lundbergii to pines in South Africa. Fungal Divers 10:229-240

Zipfel RD, De Beer ZW, Jacobs K, Wingfield BD, Wingfield MJ (2006) Multi-gene phylogenies define Ceratocystiopsis and Grosmannia distinct from Ophiostoma. Stud Mycol 55:75-97 